DOI: 10.46340/ephd.2020.6.3.7

\title{
Oleksii Yankul
}

ORCID ID: https://orcid.org/0000-0002-1244-4536

V. N. Karazin Kharkiv National University, Ukraine

\section{TO THE QUESTION OF CORRELATION \\ BETWEEN GENERAL IMPERIAL AND LOCAL INFORMATION IN «KHARKIV CALENDAR» (FOR 1869-1917)}

\author{
Олексій Янкул \\ Харківський національний університет імені В. Н. Каразіна, Україна

\section{ДО ПИТАННЯ ПРО СПІВВІДНОШЕННЯ ЗАГАЛЬНОІМПЕРСЬКОЇ ТА МІСЦЕВОЇ ІНФОРМАЦЇ̈ В «ХАРЬКОВСКОМ КАЛЕНДАРЕ» (НА 1869-1917 РР.)}

\begin{abstract}
The article examines the issues of correlation between national and local information in the obligatory statistical and information yearbook in the Russian Empire, which was issued in each province of the country. We have considered this issue on the example of the "Kharkiv calendar» (for 1869-1917). The nature of both types of publications was determined, a quantitative analysis of the materials was carried out. It was concluded that the general materials covered only some specific areas of social life (religion, finance, etc.), and local data concerned almost all the areas of life of the local population (from various statistical data on population movements to education, trade, etc.). Such a variety of information indicates that the "Kharkiv calendar» was aimed primarily at certain segments of the population of Kharkiv and the province and provided both statistical and popular science up-to-date data.

Keywords: yearbook «Kharkiv calendar», general imperial and local information, Kharkiv, Kharkiv province, analysis.
\end{abstract}

Одним з важливих джерел з історії Харківщини другої половини XIX - початку XX ст. $\epsilon$ статистико-інформаційний збірник «Харьковский календарь», який видавався в період 31868 р. до 1917 р. Харківським губернським статистичним комітетом. Редакторами випусків були секретарі комітету. На сторінках цих видань відображалися не лише статистичні дані, а й довідкові матеріали, іноді містилися науково-популярні статті, інформація щодо підприємств, різноманітних закладів тощо, які діяли в Харкові та Харківській губернії в означений період. Видання в місцевому варіанті комплексно відображало модернізаційні процеси, які охопили Російську імперію після реформ Олександра II.

«Харьковский календарь» протягом всього періоду свого існування містив матеріали, які стосувалися не лише Харкова та губернії, але й Російської імперії в цілому, а подекуди в ньому йшлося й про світові події. Причому, одразу можна зазначити, що, за нашими спостереженнями, більш «загальна інформація» (тобто та, яка стосувалася імперії та світу в цілому) займала чимале місце, особливо на початковому етапі існування збірника. В даній статті ми розглянемо ці дані, визначимо характер таких відомостей, окреслимо співвідношення місцевої інформації до загальноімперської.

У період з 1862 по 1868 pр. в Харкові місцевим губернським статистичним комітетом видавалася «Памятная книжка Харьковской губернии», яку можна вважати виданням, що передувало «Харьковскому календарю», оскільки за змістом вони були ідентичними. Починаючи з «Памятной книжки Харьковской губернии», дані, які розміщувалися на сторінках видання можна умовно поділяти на «загальні» (загальноімперські та світові) та «місцеві» (ті, які стосувалися міста Харкова, окремих повітів і Харківської губернії в цілому). Протягом всіх семи випусків цього збірника він зарекомендував себе передовсім як статистико-інформаційне видання з великою кількістю «місцевих 
відомостей». В деяких випусках «загальна інформація» відсутня взагалі (наприклад, за 1864-1865, 1867 pp. ${ }^{1}$ ). Але й $з$ перших номерів локальні дані за своєю кількістю значно перевищували імперські, а інформація про світові події обмежувалася церковно-релігійною тематикою.

Для прикладу порівняємо змістовну частину столичної «Памятной книжки СанктПетербургской губернии на 1864 год» ${ }^{2}$ з аналогічним збірником по Харківській губернії за цей же рік. Ми обрали для порівняння саме столичне видання, оскільки можна припустити, що саме воно мало бути флагманом серед подібних видань і провінційні губернські статистичні комітети повинні були рівнятися на нього при створенні своїх пам'ятних книжок і календарів.

В першому випадку місцеві матеріали, що стосувалися Санкт-Петербургу та губернії складають основну частину змісту, а будь-які дані по імперії в цілому відсутні. Так само і в Харкові регіональні дані в цей рік повністю займають весь зміст «Памятной книжки...». Це може свідчити про певний вплив столичного збірника, який, скоріш за все, був взятий Харківським губернським статистичним комітетом за взірець. Однак, варто зазначити, що, на відміну від харківського видання, в санктпетербурзькому був зручнішим навігаційний апарат. Зокрема, в змісті (який знаходився наприкінці, а не на початку, як в «Памятной книжке Харьковской губернии») ми бачимо чіткий розподіл статистичних даних за певними критеріями, наприклад: «Пространство и постройки», «Народонаселение», «Промышленность и торговля» ${ }^{3}$ тощо. Такий розподіл дозволяв читачу швидше знайти необхідну інформацію. В харківському випадку подібні дані в змісті не виділялися окремо, а просто друкувалися під загальною назвою «Статистические сведения о Харьковской губернии» ${ }^{4}$

Проте, обидва видання за своїм наповненням не є подібними. В харківському збірнику в цей рік вийшло кілька наукових статей щодо природи краю (наприклад, статті Н. Д. Борисяка «Об орографических отношениях на пространстве, занимаемом Изюмским уездом Харьковской губернии» ${ }^{5}$ та А. С. Пітри «О студенистых водорослях Змиевского Лимана (Харьковской губернии)» ${ }^{6}$ ). «Памятная книжка Санкт-Петербургской губернии на 1864 год» була суто статистистико-довідковим виданням, оскільки тут наводився адрес-календар правлячих осіб, чиновників і установ губернії та різноманітні статистичні дані. Інша інформація не зустрічається. Такого підходу видавці в Петербурзі дотримувалися й надалі.

Таким чином, ми можемо зробити висновок про те, що Харківський губернський статистичний комітет, на який було покладено видання «Календаря», орієнтуючись на столичні зразки, все ж намагався створити своє, оригінальне видання, яке, зокрема, відрізнялося завдяки публікації наукових i науково-популярних праць. Зазначимо, що викладачі та професори Харківського університету значно впливали на роботу Харківського губернського статистичного комітету зі створення пам'ятних книжок, надаючи для публікації свої наукові та оглядові розвідки, що, на нашу думку, позитивно вплинуло на змістовну частину, роблячи ії унікальною не лише для даного регіону, але й в загальноімперському масштабі.

Коли на зміну «Памятной книжке Харьковской губернии» прийшов «Харьковский календарь», пошуки оптимального змісту не припинились. Випуски «Харьковского календаря» на 1869 та 1870 pр. суттєво відрізнялись від того, що пропонувала «Памятная книжка...». Зокрема, відмінність полягала в тому, що збільшився обсяг загальноімперської інформації. У календарі на 1869 р. таких матеріалів було біля $20^{7}$, а наступного року - понад $70^{8}$. При цьому, в цих випусках місцевої інформації було більше (в другому випадку - незначно), але тільки за рахунок статистики, довідкових матеріалів (зокрема, адрес-календаря) і оголошень. Наукових і науково-популярних матеріалів в перших випусках не було. Це можна пояснити тим, що, можливо, укладач О. Й. Подвисоцький намагався створити збірник, який би відрізнявся від «Памятной книжки Харьковской губернии».

\footnotetext{
${ }^{1}$ Памятная книжка Харьковской губернии на 1864 год (1864) Харьков: В Университетской типографии, 3; Памятная книжка Харьковской губернии на 1865 год (1865). Харьков: В Университетской типографии, 4; Памятная книжка Харьковской губернии на 1867 год (1867). Харьков: В Университетской типографии, 6.

${ }^{2}$ Памятная книжка Санкт-Петербургской губернии на 1864 год (1864). Санкт-Петербург: Типография Санкт-Петербургского губернского правления, 2.

${ }^{3}$ Там само, 200-310.

${ }^{4}$ Памятная книжка Харьковской губернии на 1864 год (1864) Харьков: В Университетской типографии, 93-260.

${ }^{5}$ Памятная книжка Харьковской губернии на 1864 год (1864) Харьков: В Университетской типографии, $237-245$.

${ }^{6}$ Там само, 246-258.

${ }^{7}$ Харьковский календарь на 1869 год (1868). Харьков: Печатано в Губернской типографии, 1.

${ }^{8}$ Харьковский календарь на 1870 год (репринтное издание) (2008). Харьков: Издательство САГА, 2.
} 
Проте, вже починаючи 3 «Харьковского календаря на 1871 год», цей збірник за змістом нагадував «Памятную книжку...», але в більш розширеному варіанті.

Зазначимо, що перші чотири випуски «Харьковского календаря» (на 1869-1872 рр.) вважалися приватним виданням, хоча й були укладені секретарем Харківського губернського статистичного комітету О. Й. Подвисоцьким (1825-1883). Після того, як був виданий випуск на 1873 рік, видання стало офіційним і відлік номерів знову розпочався 3 першого. 3 того часу, коли «Харьковский календарь» став видаватися Харківським губернським статистичним комітетом (1872р.), кількість місцевої інформації поступово збільшувалася та мала значну перевагу над імперською (знов-таки, завдяки адрес-календарю). Це також пояснюється об’єднанням деяких рубрик, через що кількість матеріалів, розміщених окремо, зменшувалась. Для прикладу, у календарі на 1874 рік місцеві відомості були поділені на кілька рубрик: «Почта, телеграф, железные дороги» ${ }^{1}$, «Статистический отдел» ${ }^{2}$ та деякі інші. Через 10 років у календарі на 1884 р. дані з цих розділів були об'єднані в «Отдел III-й местный справочный» ${ }^{3}$.

Зауважимо, що всі цифри, наведені нами стосовно «Харьковского календаря» подані без урахування довідок, які друкувалися в адрес-календарі, але в місцеву інформацію окремо рахувалися також різноманітні додатки, якщо вони були. Кількість матеріалів як загальних, так і місцевих вказана приблизно, оскільки в ході підрахунків могли бути незначні погрішності.

Починаючи 3 «Харьковского календаря» на 1874 р. кількість загальноімперської інформації поступово почала скорочуватись. Так, у виданні на цей рік і на наступний 1875 р. таких матеріалів окремими статтями налічувалось 34 , місцевих - понад $30^{4}$, а вже у 1877 р. кількість загальної інформації скоротилась до 24, місцевих відомостей знову було понад $30^{5}$. У календарі на 1878 р. загальна інформація складала вже 32 матеріали, місцева $-42^{6}$, а на наступний рік місцева інформація зросла до 51, загальна зменшилася до 29 матеріалів ${ }^{7}$.

У 1880-ті роки (на нашу думку, це був період розквіту «Харьковского календаря») інформація місцевого характеру спочатку залишилася на тому ж рівні за кількістю, як і наприкінці 1870-х рр. Однак ситуація була дещо іншою порівняно з попередніми періодами. Були спроби об'єднання матеріалів в укрупнених розділах. Особливо виразно це простежується у випуску на 1882 р., коли загальні матеріали складали 11 позицій, а місцеві $-24^{8}$. Майже те саме простежується наступного року (загальні - 16, місцеві - 21) ${ }^{9}$. Положення почало змінюватися в період, коли редактором «Харьковского календаря» став відомий історик, етнограф П. С. Єфименко (1836-1907). В цей час кількість місцевих повідомлень значно перевищувала загальну в порівнянні з попередніми роками. У виданні на 1884 p. ii кількість збільшилась до 69 матеріалів (загальних було 21) ${ }^{10}$, а вже у 1885 р. ця цифра зросла до 133 (загальних - 59) ${ }^{11}$. Це відбулося ще й тому що з цього року в збірнику з'явився новий розділ медичний, де містилася велика кількість інформації щодо лікарень міста Харкова, приватних клінік, наводилася статистика різноманітних захворювань тощо ${ }^{12}$. У випуску на 1887 р. кількість місцевих матеріалів досягла вищої позначки - 156 (загальних - 86) ${ }^{13}$. При цьому зазначимо, що в цей же рік значно збільшилась і кількість сторінок «Календаря»- 1043 при 892-х сторінках в попередньому збірнику ${ }^{14} .31889$ р. в збірнику вже спостерігається зниження кількості окремої інформації як місцевого (96), так і загального характеру (47) $)^{15}$. Це пов'язано 3 подальшими пошуками оптимального комплектування розділів, які спостерігаються безперервно протягом всього часу існування збірника.

\footnotetext{
${ }^{1}$ Харьковский календарь на 1874 год (1873). Харьков: Печатня К. П. Счасни, 2, 109-161.

2 там само, 262-322.

${ }^{3}$ Харьковский календарь на 1884 год. Харьков: Типография Губернского правления, 12, 116-341.

${ }^{4}$ Харьковский календарь на 1874 год (1873). Харьков: Печатня К. П. Счасни, 2; Харьковский календарь на 1875 год (1874). Харьков: Типография И. Д. Гинзбурга и А. Я. Кудрина, 3.

${ }^{5}$ Харьковский календарь на 1877 год (1876). Харьков: Типография Харьковского губернского правления, 5.

${ }^{6}$ Харьковский календарь на 1878 год (1877). Харьков: Типография Губернского правления, 6.

${ }^{7}$ Харьковский календарь на 1879 год (1878). Харьков: Типография Харьковского губернского правления, 7.

${ }^{8}$ Харьковский календарь на 1882 год (1882). Харьков: Типография К. П. Счасни, 10.

${ }^{9}$ Харьковский календарь на 1883 год (1882). Харьков: Типография Харьковского губернского правления, 11.

${ }^{10}$ Харьковский календарь на 1884 год (1883). Харьков: Типография Губернского правления, 12.

${ }^{11}$ Харьковский календарь и памятная книжка на 1885 2. (1884). Харьков: Типография Губернского правления, 13.

12 Там само, 260-321.

${ }^{13}$ Харьковский календарь на 1887 год (1886). Харьков: Типография Губернского правления, 15.

${ }^{14}$ Харьковский календарь на 1886 год (1885). Харьков: Типография Губернского правления, 14.

${ }^{15}$ Харьковский календарь на 1889 год (1889). Харьков: Типография Губернского правления, 17.
} 
У 1890-х рр. стан змістовної частини знову почав змінюватись. У порівнянні з випуском на 1889 рік, з наступного збірника кількість інформації (як загальної, так і місцевої) почала зменшуватись (близько 42 позиції загальних та 69 місцевих матеріалів) ${ }^{1}$. Подібна ситуація спостерігалася й у 1891 р. (47 - загальна інформація, 52 - місцева $)^{2}$. Але вже з випуску на 1892 р. кількість матеріалів поступово збільшувалась (82 загальних, 77 місцевих) ${ }^{3}$ і до 1898 р. зростала. В цей же час з'являються нові розділи (наприклад, «Отдел статистический областной» ${ }^{4}$, в якому містилася інформація про деякі інші губернії Російської імперії, перш за все - розташованих найближче до Харківської (Курську, Воронезьку, Чернігівську, Полтавську та ін.) рубрики (наприклад, «Вновь изданные узаконения и распоряжения» ${ }^{5}$ та ін.). Проте, в цей період деякі вже традиційні рубрики поступово скорочувались (наприклад, медичний відділ ${ }^{6}$ ) і ця тенденція зберігалася до останнього випуску на 1917 рік.

Перший випуск, де кількість місцевої інформації перевищила 200 позицій, був випуск на 1894 р. (231 матеріал) $)^{7}$. Це було пов’язано 3 двома новими рубриками: торговою та педагогічною, про що читачам повідомлялося в передмові ${ }^{8}$.

Найбільша кількість місцевої інформації за весь період існування видання спостерігається у збірнику на 1897 р. - 266 (загальної - 89) . В даному випадку збільшення матеріалів, скоріше за все, було пов'язане з тим, що цей випуск оголошувався «ювілейним», про що йшлося в передмові: «В текущем 1897 году исполнилось [...] 25 лет изданию «Харьковского календаря» и 35 лет изданию статистическим комитетом научно-справочных книг [мається на увазі початок випуску «Памятной книжки Харьковской губернии»- О.Я.]» ${ }^{10}$. Якщо брати до уваги той факт, що Харківський губернський статистичний комітет починав відлік «Харьковского календаря» з випуску на 1873 рік (опублікований у 1872 р.), коли видання припинило бути приватним, а видавалося комітетом, то у 1897 р. збірнику виповнювалося 25 років, хоча, на нашу думку, в дослідженнях варто враховувати випуски, які виходили друком, починаючи з 1868 року.

1898 року кількість інформації зменшилася: 57 загальної (ії вже не було в адрес-календарі) та 49 місцевої (без урахування адрес-календаря) ${ }^{11}$, а вже з 1899 року знову зросла (62 загальної та 173 місцевої $^{12}$ ) і така тенденція збереглася до 1906 p. (за період з 1899 р. до 1906 р. найбільша кількість місцевої інформації була на сторінках видання за 1903 р. $(221)^{13}$, а загальноїy 1902 p. $(77)^{14}$.

При цьому, в цей період деякі відділи змінюють свій напрямок. Наприклад, медичний, який став містити лише інформацію про лікарів, масажистів Харкова та інших медиків і став нагадувати більше адрес-календар, а не окремий відділ з актуальною інформацією про різноманітні хвороби, способи їх лікування та інше, як це було раніше ${ }^{15}$.

31907 p. обсяг всієї інформації зменшувалася. Це було пов'язано з черговим перекомплектуванням розділів. В даному випадку «Харьковский календарь» перейшов до розряду статистико-довідкових видань, зберігаючи при цьому суто довідковий стиль викладення матеріалу, оскільки окрім статистики, різноманітних довідкових даних і реклами у виданні більше нічого не було. Такий перехід міг бути пов'язаний з кризою в статистичному комітеті, або зі зміною кадрового складу, який вирішив зробити видання більш вузького спрямування, як це й було, за нашими спостереженнями, здебільшого в інших губерніях. В цей час у виданні також проходять деякі зміни в змістовній частині. 3 випуску «Харьковского календаря на 1911 год» з'являється новий

\footnotetext{
${ }^{1}$ Харьковский календарь на 1890 год (1890). Харьков: Типография Губернского правления, 18.

${ }^{2}$ Харьковский календарь на 1891 год (1891). Харьков: Типография Губернского правления, 19.

${ }^{3}$ Харьковский календарь на 1892 год (1892). Харьков: Типография Губернского правления, 20.

${ }^{4}$ Харьковский календарь на 1893 год (1893). Харьков: Типография губернского правления, 21.

${ }^{5}$ Харьковский календарь на 1892 год (1892). Харьков: Типография Губернского правления, 20, $124-211$.

${ }^{6}$ Харьковский календарь на 1893 год (1893). Харьков: Типография губернского правления, 21, 319-333.

${ }^{7}$ Харьковский календарь на 1894 год (1894). Харьков: Типография Губернского правления, 22.

${ }^{8}$ Харьковский календарь на 1894 год (1894). Харьков: Типография Губернского правления, 22, XVII.

${ }^{9}$ Харьковский календарь на 1897 год (1897). Харьков: Типография Губернского правления, 25.

10 Там само, А.

${ }^{11}$ Харьковский календарь на 1898 год (1898). Харьков: Типография Губернского правления, 26.

${ }^{12}$ Харьковский календарь на 1899 год (1899). Харьков: Типография Губернского правления, 27.

${ }^{13}$ Харьковский календарь на 1903 год (1903). Харьков: Типография Гессен, Молчадского и Варшавчика, 31.

${ }^{14}$ Харьковский календарь на 1902 год (1902). Харьков: Типографии Варшавчика, Гессена и Молчадского, 30.

${ }^{15}$ Харьковский календарь на 1906 год (1906). Харьков: Типография губернского правления, 34, 150-168.
} 
розділ «Список обществ Харьковской губернии» ${ }^{1}$, а також 3 цього ж випуску підрозділ «Фабрики и заводы» ${ }^{2}$ став окремим розділом (до того розміщувався в «Отделе статистическом местном» ${ }^{3}$ ). Крім того, додавався ще один окремий розділ, якого до того не було на сторінках збірника - «Обзор Харьковской губернии» за якийсь певний рік (наприклад, в «Харьковском календаре на 1911 год» такий огляд губернії був за 1909 р. ${ }^{4}$ ). Цей розділ репрезентував різноманітні статистичні дані у вигляді таблиць та містив загальні огляди. Він складався 3 таких підрозділів: «Пространство, естественные и производительные силы губернии и экономическая деятельность её населения» 5 , «Земледелие» ${ }^{6}$, «Скотоводство» ${ }^{7}$ та ін.

В період з 1907 р. до 1917 р. максимальна кількість місцевої інформації сягнула 18 (збірники на 1911-1916 pp. $)^{8}$, а загальної - 24 (видання на 1907-1908 pp.) $)^{9}$. Найменшим за обсягом змісту був «Харьковский календарь» на 1917 р., оскільки в ньому були лише загальні розділи «Российский императорский дом» та «Месяцеслов» і місцеві «Административный отдел», «Адрес-календарь» і «Объявления» ${ }^{10}$.

Варто зазначити, що частину матеріалів «Харьковского календаря» можна віднести до світового контексту. Така інформація стосувалася, як правило, релігії та церкви (не лише православного сповідання) і розміщувалася в розділі «Месяцеслов»"${ }^{11}$, астрономічних відомостей (наприклад, «О различии в показании часов в один и тот же момент в различных местах Земли», «Таблица сравнения харьковского времени с временем других мест Земли» ${ }^{12}$ ), політичної (наприклад, «Государи и правители стран» ${ }^{13}$ ), торгової та фінансової сфери (наприклад, «Сравнение единиц меры и веса иностранных с употребляемыми в России», «Употребительнейшие иностранные монеты с обозначением их стоимости в рублях и копейках» ${ }^{14}$ ) та ін. Подібні матеріали зустрічаються рідше, аніж інші повідомлення, проте вони знайомили читачів з актуальними відомостями, які виходили за межі губернії та імперії.

Таким чином, «Харьковский календарь» можна віднести до універсальних видань, оскільки він поєднував у своєму змісті необхідну та актуальну інформацію як загальноімперського напрямку, так і місцеву. Однак, загальні відомості виконували більше формальну «обов’язкову» функцію та не відрізнялися особливим розмаїттям матеріалів. Вони розміщувалися, скоріш за все, з метою донести загальну, перш за все - обов'язкову інформацію (щодо законів, певних фактів з історії та сучасності Російської імперії, всіляких тарифів та інших послуг) до відома населення. В той же час місцеві дані мали інший характер. Тут також була загальна інформація щодо тарифів, послуг та інше, але в губернському та міському вимірі. Втім, на цьому зміст збірника не обмежувався. В деяких випусках містилися наукові та науково-популярні статті, статистичні та історичні матеріали, які відбиралися членами комітету і стосувалися майже всіх сфер життя суспільства. Такі публікації мали більш різноманітну спрямованість. Багато з них визначалися укладачами, роблячи зміст унікальним, притаманним лише Харківській губернії.

\footnotetext{
${ }^{1}$ Харьковский календарь на 1911 год (1910). Харьков: Типография Губернского правления, 39, 111-124.

2 Там само, 125-167.

${ }^{3}$ Харьковский календарь на 1900 год (1900). Харьков: Типография Варшавчика, 28, 144.

${ }^{4}$ Харьковский календарь на 1911 год (1910). Харьков: Типография Губернского правления, 39, 1-81.

5 Там само, 1-4.

${ }^{6}$ Там само, 4-14.

7 Там само, 14-16.

${ }^{8}$ Харьковский календарь на 1911 год (1910). Харьков: Типография Губернского правления, 39; Харьковский календарь на 1912 год (1911). Харьков: Типография Губернского правления, 40; Харьковский календарь на 1913 год (1912). Харьков: Типография Губернского правления, 41; Харьковский календарь на 1914 год (1913). Харьков: Типография Губернского правления, 42; Харьковский календарь на 1915 год (1914). Харьков: Типография Губернского правления, 43; Харьковский календарь на 1916 год (1915). Харьков: Типография Губернского правления, 44.

9 Харьковский календарь на 1907 год (1907). Харьков: Типография Губернского правления, 35; Харьковский календарь на 1908 год (1908). Харьков: Типография Губернского правления, 36.

${ }^{10}$ Харьковский календарь на 1917 год (1916). Харьков: Типография Губернского правления, 45.

${ }^{11}$ Харьковский календарь на 1869 год (1868). Харьков: Печатано в Губернской типографии, 1; Харьковский календарь на 1917 год (1916). Харьков: Типография Губернского правления, 45, 3-38.

12 Харьковский календарь на 1873 год (1872). Харьков: Печатня К. П. Счасни, 1, 18-21.

${ }^{13}$ Харьковский календарь на 1903 год (1903). Харьков: Типография Гессен, Молчадского и Варшавчика, 31, $303-304$.

${ }^{14}$ Харьковский календарь на 1876 год (1875). Харьков: Типография губернского правления, 4, 331-334.
} 
До 1880-х рр. загальної інформації було дещо більше, а кількість місцевих матеріалів отримувала перевагу здебільшого за рахунок адрес-календаря установ, керуючих осіб губернії тощо. 3 того моменту, як секретарем Харківського губернського статистичного комітету став П. С. Єфименко, кількість місцевих відомостей почала збільшуватись й поступово зростала за рахунок нових розділів, які з'являлися у виданні та розширенні традиційних. Так, з випуску на 1884 р. у збірнику з'явився окремий розділ, присвячений науковим і науково-популярним статтям, який продовжився до випуску на 1886 р., а з 1887 р. зник, оскільки для таких матеріалів з'явився спеціальний додаток до збірника - «Харьковский сборник».

3 початку 1890-х рр. «Харьковский календарь» поступово стає, скоріше, не статистикоінформаційним (тобто таким, який мав у собі не лише статистику та довідкові матеріали, але й інформацію, яка виходила за ці межі, наприклад, науково-популярні статті, огляди тощо), а статистико-довідковим виданням (таким, яке містило в собі здебільшого суто статистику та довідкову інформацію, оскільки його зміст поступово скорочувався (з деякими перервами зменшувалися й традиційні для «Харьковского календаря» розділи). 31907 р. спостерігаються спроби зробити видання більш компактним, завдяки чому обсяг інформації зменшувався. В цей період ми вже не бачимо жодних нових розділів, а викладення матеріалу в збірнику стає більш лаконічним, роблячи його вузькоспрямованим.

Якщо загальні матеріали охоплювали лише деякі конкретні сфери життя суспільства (релігія, фінансова сфера, залізничні та телеграфні відомості), то регіональні дані стосувалися практично всіх сфер життя місцевого населення. До того ж, їх було більше в кожному випуску (якщо брати до уваги також адрес-календар). Таке розмаїття інформації свідчить про те, що «Харьковский календарь» був спрямований в першу чергу на певні верстви населення міста Харкова та губернії та надавав актуальні на той час дані як статистичного, так і науково-популярного характеру.

\section{References:}

1. Harkovskij kalendar na 1869 god (1868) [Kharkiv Calendar for 1869]. Kharkiv: Pechatano v Gubernskoj tipografii, 1 [in Russian].

2. Harkovskij kalendar na 1870 god (reprintnoe izdanie) (2008) [Kharkiv Calendar for 1870 (reprint edition)]. Kharkiv: SAGA, 2 [in Russian].

3. Harkovskij kalendar na 1871 god (1870) [Kharkiv Calendar for 1871]. Kharkiv: Tipografija K. P. Schasni, 3 [in Russian].

4. Har'kovskij kalendar' na 1872 god (1871) [Kharkiv Calendar for 1872]. Kharkiv: Tipografija K. P. Schasni, 4 [in Russian].

5. Harkovskij kalendar na 1873-1917 god (1872-1916) [Kharkiv Calendar for 1873-1917]. Kharkiv, 1-45 [in Russian].

6. Pamjatnaja knizhka Harkovskoj gubernii na 1862-1868 god (1862-1868) [Memorable Book of the Kharkiv Province for 1862-1868]. Kharkiv: V Universitetskoj tipografii, 1-7 [in Russian].

7. Pamjatnaja knizhka Sankt-Peterburgskoj gubernii na 1863-1868 god (1864) [Memorable Book of the Saint Petersburg Province for 1863-1868]. Saint Petersburg: Tipografija Sankt-Peterburgskogo gubernskogo pravlenija, 1-6 [in Russian]. 